DOI: $10.33067 /$ SE.1.2021.8

Haki Demolli $\star$

Islam Qerimi ${ }^{\star \star}$

\title{
Kosovo's Legislation and Other Mechanisms on Counterterrorism
}

\begin{abstract}
In this paper, we discuss terrorism as an adversity to global security, with special emphasis on Kosovo. The presented data shows that today, terrorism poses a risk to more than half of the world's population. Although a small country, Kosovo, has not been left out of this negative societal phenomenon. More specifically, according to international reports, the threat and danger to Kosovo from Islamic extremism has increased; it is supported and partially funded by foreign organisations that propagate extremist ideology and violent extremist groups which use social networks in a very active way to propagate and recruit their followers. The data in this paper confirms that more than 400 Kosovar men, women, and children have travelled to areas of armed conflict in Syria and Iraq, having been recruited to fight for violent extremist groups. Therefore, the clear policies of the Government of the Republic of Kosovo addressed here suggest the government is aware of the seriousness of this threat which it is determined to prevent and combat this phenomenon by taking concrete steps in areas such as: legislative measures; mechanisms and planning for the prevention of and combat against terrorism as well as being proactive in the fight against terrorism.
\end{abstract}

Keywords: Terrorism, Extremism, Global Security, National Security, Kosovo

^ Haki Demolli - University of Prishtina/Kosovo, e-mail: haki.demolli@uni-pr.edu, ORCID: 0000-0002-5995-5093.

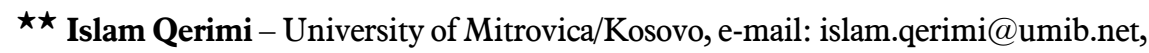
ORCID: 0000-0002-1645-079X. 


\section{Introduction}

In the contemporary world, terrorism is considered one of the most serious threats not only to the national security of a given country, but also to international security and the lives of human beings around the globe. Terrorism is simply a threat to global security that knows no borders and strikes both states and their populations, regardless of the geographical area in which they lie and operate. However, until September 11th 2001, only six European Union countries (England, France, Germany, Italy, Portugal, and Spain) had enacted special laws and measures to prevent and combat terrorism. ${ }^{1}$ It is worth emphasising that the leaders of EU countries have drafted strategies and have undertaken joint measures to prevent and successfully combat terrorism for the safety of EU citizens. After studying terrorist activities, the resultant empirical data we present in this paper shows that during the 14-year study period (2006-2019) 282,431 people have lost their lives as a result of terrorist acts in the world or, as a per annum average, 20,173 people have been killed, hundreds of thousands injured and material damage worth hundreds of billions of euros has been caused due to terrorist acts. ${ }^{2}$

According to the Institute for Economics and Peace in 2019, in 103 countries at least one terrorist act was committed, which is a much larger number than in 2013, during which the phenomenon of terrorism was present in 59 states. $^{3}$ In fact, in 2019, from $195^{4}$ countries, 103 of them, or $52.8 \%$ of those countries, were affected by the terrorism phenomenon.

Europe continued to face many ongoing terrorist threats and concerns in 2019, including from U.S.-designated FTOs, FTFs returning from Iraq and Syria, home-grown terrorists, and Iran-backed terrorists. Despite the total loss of its geographic territory, ISIS continued to project its influence by fomenting attacks against symbolic European targets and public spaces and recruiting from European countries. Most of these incidents occurred in Western Europe and Russia and involved simple plots with

1 I. Qerimi, Einige Fakten und Ansichten des Terrorismus in ex-Fugoslawien: Die Albaner unter der einhundertjährigen jugoslawiscen Herschaft, GRIN Publishing GmbH, Munich 2004, p. 7.

2 https:/www.statista.com/statistics/202871/number-of-fatalities-by-terroristattacks-worldwide (access 20.05.2020); Global Terrorism Index 2020: Measuring the Impact of Terrorism, Institute for Economics and Peace, Sydney, November 2020, p. 1.

3 Ibidem, p. 12.

4 According to data from Bureau of Intelligence and Research, Washington, DC, on "Independent states of the world", published on January $20^{\text {th }} 2017$, there are 195 independent states in the world, https://www.state.gov/s/inr/rls/4250.htm (access 20.06.2020). 
easily executable tactics, such as the use of common tools and vehicles to injure or kill pedestrians. ${ }^{5}$

Therefore, we think that Rowan Howard-Williams rightly pointed out that threats from terrorist attacks weaken the trust of citizens in state institutions and that shortcomings in the governance of some weak states negatively affect the capacity building of transnational terrorists. ${ }^{6}$

Author Ulrich Beck, when talking about the "dangers of society", emphasises that human society is currently threatened by two main types of risks and they are:

a. Natural disasters or so-called "Acts of God", which are beyond human control and,

b. The dangers that are a result of human actions, such as terrorism, climate change, nuclear war, etc. By comparing terrorism with natural disasters and nuclear wars, we consider that such a division of serious risks to the society, respectively to global security, is a fair comparison, is completely reasonable and can be argued with an analysis of the data on the consequences and spread of terrorism in recent years in the world. ${ }^{7}$

\section{The Risk of Terrorism in Kosovo}

Despite the fact that no terrorist acts were committed in Kosovo during $2019,{ }^{8}$ this small country is also threatened by terrorism. More specifically, according to international reports, the threat and danger from Islamic extremism has increased against Kosovo, supported and partially funded by foreign organisations that propagate extremist ideology and violent extremist groups, which use social networks in a very active way to propagate and recruit their followers.

It is known that more than 400 Kosovar men, women and children have travelled to areas of armed conflict in Syria and Iraq in order to fight either for the Islamic State or for Al Nusra (an Al-Qaeda branch in Syria).

5 US Department of State (Bureau of Counterterrorism); Country Reports on Terrorism 2019, p. 60, www.state.gov/wp-content/uploads/2020/06/Country-Reports-onTerrorism-2019-2.pdf (access 28.01.2021).

${ }^{6}$ R. Howard-Williams, Terrorism and World Risk Society: Resilience, Resentment, and Spectacle, Printer-friendly version, Series ISIS Media, vol. 10, issue 70, October 2017, p. 1.

7 V. Latifi, H. Demolli, Kriminalistika (Forensics), Fakulteti Juridik, Prishtinë 2019, p. 415.

8 US Department of State (Bureau of Counterterrorism); Country Reports on Terrorism 2019, p. 88, www.state.gov/wp-content/uploads/2020/06/Country-Reports-onTerrorism-2019-2.pdf (access 28.01.2021). 
Around 70 of those people have lost their lives, while 130 have returned to Kosovo and 200 remain in the conflict zones. ${ }^{9}$

Therefore, given the above facts, it can be argued that Kosovo is not immune to this threat or phenomenon. With such facts taken into account by the government and other relevant institutions of Kosovo they have been treated with special consideration and in a very serious manner.

In this regard, the Government of the Republic of Kosovo, aware of the seriousness of this threat on the European continent, has defined clear policies to countering terrorism and has taken concrete measures in certain areas:

1. Measures in terms of legislation;

2. Mechanisms for the countering of terrorism;

3. Planning the countering of terrorism and

4. Concrete activities in the countering of terrorism.

\section{Addressing Terrorism in the Legislation of Kosovo}

Among the main laws of Kosovo, which incriminate and deal with terrorism, are:

a. The Criminal Code of the Republic of Kosovo;

b. The Law on Prevention of Money Laundering and Combating Terrorist Financing;

c. A law on the prohibition of joining armed conflicts outside state territory, and

d. The Law on Critical Infrastructure.

\section{Incrimination of the Terrorist Offences in the Criminal Code of the Republic of Kosovo (CCK) ${ }^{10}$}

The CCK addresses the issue of terrorism fairly well, however, only some of the main features of the criminal legal treatment of this phenomenon will be emphasised here, namely:

a.a. The definition of terrorism as a criminal offence, but also all other acts related to terrorism, are addressed in Chapter XIV (entitled "Criminal offences against the constitutional order and the security of the Re-

${ }^{9}$ Ll. Semini, F. Bajrami, 110 Kosovars, mostly children and women, returned from Syria, “The Seattle Times", April 20, 2019, www.seattletimes.com/nation-world/world/110kosovars-mostly-children-and-women-returned-from-syria/ (access, 29.01.2021).

${ }_{10}$ No. 06/L-074 The Criminal Code of the Republic of Kosovo, approved by the Assembly of Kosovo, on 23.11.2018, entered into force 3 months after the publication in the Official Gazette of Kosovo on 14.01.2019. 
public of Kosovo"). This chapter, alongside terrorism, refers to other criminal acts as well, by means of which the integrity and sovereignty of the country may be threatened, as well as the functioning of the state in general, such as attacks against the constitutional order of the Republic of Kosovo; acceptance of capitulation and occupation; armed uprising; treason; endangering of the territorial integrity of the Republic of Kosovo; espionage, and sabotage among others.

b.b. The CCK defines terrorism as a criminal offence, specifying the actions and motives for perpetration, respectively the constituent elements of this criminal offence. The definition of terrorism is made not only for the needs of the CCK, but also for the needs of other laws of Kosovo which are related to the prevention and fighting of terrorism. Specifically, Article 128 of the CCK defines terrorism, through which the following elements of this criminal offence can be emphasised:

The act of committing terrorism; the act by which one or more criminal offences (totalling 19 in number) are committed, namely specified within this article, starting from murder or aggravated murder; incitement or assisted suicide; attack with minor injury or serious bodily injury; acts against sexual integrity; the taking of hostages, kidnapping or the unlawful deprivation of liberty; causing general danger, arson or burning or explosion; the pollution of drinking water or food products, the pollution or destruction of the environment, and so on.

- The purpose of committing any of the acts listed specifically; one or more of the above criminal offences can be considered as terrorism, if it is committed, with an intent, to:

a) Seriously intimidate a population, or

b) Unduly compel a public entity, government or international organisation to do or abstain from doing any act, or

c) Seriously destabilise or destroy the fundamental political, constitutional, economic or social structures of the Republic of Kosovo, another State or an international organization.

c.c. In the CCK, in addition to the criminal offence of terrorism, all other actions that in one way or another are related to the phenomenon of terrorism are defined and sanctioned. Among other things, the following actions are defined or incriminated: "Funds"; "Material resources"; "A structured group"; "Terrorist group"; "Terrorist"; then assistance in the commission of terrorism; facilitation and financing of the commission of terrorism; tecruitment for terrorism; training for terrorism; incitement to commit a terrorist offence; organisation and participation in a terrorist group; concealment or failure to report terrorists or terrorist groups; travelling for the purpose of terrorism; and the preparation of 
terrorist offences or criminal offences against the constitutional order and security of the Republic of Kosovo.

d.d. In the CCK, the criminal sanctions set for criminal offences of a terrorist nature are among the harshest. This, in fact, indicates the serious approach of the Kosovar legislators to the phenomenon of terrorism and to perpetrators who act in any form (such as in the assistance, encouragement, training, recruitment, preparation, concealment of terrorists, etc.) which is associated with terrorism. Thus, for example, in accordance with paragraph 3 of Article 129 of the CCK, in cases where a terrorist offence results in the death of one or more persons, the perpetrator shall be punished by being imprisoned for at least fifteen (15) years or even life imprisonment. So, the perpetrators of the criminal offence of terrorism can be sentenced to life imprisonment, which is one of the most severe punishments defined in contemporary criminal legislation, in general.

\section{Countering Terrorism with the Provisions of the Law on Prevention of Money Laundering and Combating Terrorist Financing ${ }^{11}$}

The focus of this law is on two illegal phenomena which are not only interrelated, but have a major impact on the occurrence of the phenomenon of terrorism in general, namely: the phenomenon of "money laundering" and the phenomenon of the financing of terrorism. Unfortunately, both of these phenomena exist to a large extent in the Republic of Kosovo.

The Assembly of Kosovo, by approving this law, has not only implemented the EU Directive 2015/849 and that of the Council of Europe of May 20th 2015, to prevent the use of the financial system for the purposes of money laundering and financing of terrorism, but at the same time it has determined the measures, the competent authorities and the procedures for the detecting and preventing of money laundering along with the combating of terrorist financing.

It should be noted that the competent Kosovar institutions in this field had acted before the approval of this law, because during 2015 they suspended the work of 13 non-governmental organisations (NGO's), on suspicion of supporting and financing extremist and terrorist activities of individuals and certain groups. Also, in early 2016, a businessman was arrested in the city of Peja on suspicion of financing terrorist groups.

11 Law no. 05/L-096 on the prevention of money laundering and combating terrorist financing, approved by the Assembly of Kosovo, May 2016. 


\section{The Prevention of Terrorism and the Law on the Prohibition of JoiningArmed Conflicts Outside the State Territory ${ }^{12}$}

According to the sponsor of the Law on the Prohibition of Joining in Armed Conflicts outside the State Territory, this law will have two main purposes, namely: (a) national security and (b) the state interest. It is estimated that this law will affect national security, because according to studies and analyses of the Kosovo authorities, people who go to certain conflicts also join various terrorist organisations, and then the inspiration they find there, tends to transfer to others by organising, calling, and recruiting not only for participation in such conflicts but also for various terrorist activities.

According to the Kosovo Ministry of Internal Affairs (MIA), by the time the law was approved, about 300 people from Kosovo had been involved in the fighting in Syria and Iraq. ${ }^{13}$

\section{The Prevention of Terrorism with the Law on Critical Infrastructure ${ }^{14}$}

With the law on critical infrastructure, the Republic of Kosovo aims to preserve and protect the national and European critical infrastructure as well as its citizens from various attacks, be they terrorist or attacks of another nature. It also aims to help prevent incidents and minimise potential damage to critical infrastructure, overall wealth, and economic and social losses.

This law regulates the national critical infrastructure of the Republic of Kosovo and provides instructions for the identification of infrastructures that will be defined as European critical infrastructure. This law also identifies sectors and criteria of critical national and European infrastructure and provides guidelines for their management, including risk analysis (including that of the risk of terrorism), security plan features for owners/operators, the roles and responsibilities of security

${ }_{12}$ Law no. 05/L-1-002 on the Prohibition of joining the armed conflicts outside state territory, approved by Assembly of Kosovo, March 2015.

${ }_{13}$ G. Kraja, The Islamic State Narrative in Kosovo Deconstructed One Story at a Time, Kosovar Center for Security Studies (KCSS), Prishtina, September, 2017, p. 5

${ }^{14}$ Law no. 06/L-014 On critical infrastructure, approved by the Assembly of Kosovo, March 2018 and is in full compliance with the EU Council Directive 2008/114/EC dated 08.12.2008 on identification and designation of European critical infrastructures and the assessment to improve their protection. 
coordinators of critical infrastructure, as well as penalties for non-compliance.

\section{Kosovo's Main Mechanisms on Countering Terrorism}

In order to successfully counter terrorism, the Republic of Kosovo, in addition to approving the necessary legislation, has also built institutional mechanisms which deal with the drafting and implementation of state policies in the prevention and fighting of such phenomenons. These mechanisms play an important role in the coordination of the activities towards fighting terrorism in Kosovo.

However, among the institutions with responsibilities and competencies in this field, specifically the institutions which are on the front line against terrorism, are: The Ministry of Internal Affairs, the Kosovo Police, the National Coordinator against Terrorism (KNKT), Prosecutions, Courts, Kosovo Intelligence Agency, etc.

Also on the front lines of countering terrorism in Kosovo are some ministries of the Government of Kosovo, as well as other institutions operating in Kosovo, such as: the Ministry of the Kosovo Security Force (which can make a significant contribution with their own activity); the Ministry of Finance; the Ministry of Justice; the Ministry of Education; the Kosovo Security Council; the Financial Intelligence Unit; ICITAP; EULEX; and OSCE among others.

Undoubtedly, the most specialised institution in this field is the National Coordinator Against Terrorism which is the individual body responsible for coordinating, monitoring and reporting on the implementation of policies, activities and actions related to the fight against terrorism which is helped and supported by the Secretariat of the National Coordinator Against Terrorism and which has as its basic duty and responsibility the collection of information and data from other institutions in order to analyse and evaluate that information, as well as the preparation of analytical reports for the KNKT.

In addition, the Ministry of the Interior, jointly with the Kosovo Police and its other mechanisms, assist in providing information and undertake activities in the prevention, protection, prosecution, and response to all terrorist activities. Within the Kosovo Police there operates the Directorate Against Terrorism which is responsible for counter-terrorism investigations and which, in recent years, has increased its own investigative capabilities. It has also increased the number of personnel and established the cyber terrorism unit.

Another important institution in the fight against terrorism in Kosovo is the Kosovo Intelligence Agency which collects, analyses, and dissemi- 
nates information in order to prevent terrorist activities taking place to the detriment of the security of the Republic of Kosovo and global security.

Yet another mechanism involved in counterterrorism in Kosovo, is EULEX. Launched in 1999, the European security and defence policy $\left(\mathrm{ESDP}^{15}\right) /$ common security and defence policy (CSDP) was not conceived as a tool to fight terrorism. After that point in time, however, the number of completed CSDP missions rose to 15 and were spread across different regions, notably Africa, the Balkans, Eastern Europe, the Middle East, Afghanistan, and Indonesia. Military missions involved up to 7000 personnel (as did Operation Althea, in 2004), while in civilian missions this number has risen to more than 2500 persons (EULEX ${ }^{16}$ Kosovo). Despite this diversity at all levels, it remains that CSDP operations' mandates have not been directly linked to combating terrorism. ${ }^{17}$

One of the CSDP's mission in the Balkans whose mandate pointed to counter-terrorism tasks is EULEX Kosovo, an extensive rule of law mission launched on 9th December 2009 (Council Joint Decision 2008/124/ CFSP) with the mandate of assisting the then newly founded Kosovo judicial institutions in the creation of a state genuinely based on the rule of law. The reference to terrorism is found in the mission's mandate, where it is stated that one of its objectives is to ensure that cases of war crimes, terrorism, organised crime, corruption, inter-ethnic crimes, financial/economic crimes, and other serious crimes are properly investigated, prosecuted, adjudicated, and enforced, according to the applicable law. ${ }^{18}$ The mission of EULEX implemented this mandate through the Strengthen-

15 The ESDP was established in 1999. The Treaty of Lisbon, signed in 13 December 2007, changed this policy's name to CSDP. Throughout this document we shall use the acronym CSDP unless quoting documents referring to ESDP.

${ }_{16}$ The European Union Rule of Law Mission in Kosovo, known as Eulex Kosovo or simply as EULEX, is the largest civilian mission ever launched under the Common Security and Defence Policy (CSDP) of the European Union. EULEX supports selected Kosovo rule of law institutions on their path towards increased effectiveness, sustainability, multi-ethnicity and accountability, free from political interference and in full compliance with international human rights standards and best European practices through monitoring activities and limited executive functions with the aim of handing over remaining tasks to other long-term EU instruments and phasing out residual executive functions. The Mission's mandate covered the period until 14 June 2020 based on Council Decision CFSP 2018/856 and has been extended to 14 June 2021 by Council Decision CFSP 2020/792. EULEX works within the framework of UN Security Council Resolution 1244.

17 B. Oliveira Martins, L. C. Ferreira-Pereira, Stepping inside? CSDP missions and EU counterterrorism, "European Security”, vol. 21, no. 4, December 2012, p. 537.

18 Ibidem, p. 544. 
ing Division (Monitoring, Mentoring, and Advising) and the Executive Division.

EULEX had an executive mandate in the Kosovo justice system from 2008 until June 14th, 2018. During that period, a total of ten terrorism cases were prosecuted by the prosecutors of this Mission. ${ }^{19}$

The Strengthening Division (SD), in full and close cooperation with other EU actors, supported Kosovo's rule of law institutions at the senior management level in their progress towards sustainability and accountability. It aimed to strengthen the chain of criminal justice, with an emphasis on fighting political interference, through monitoring, mentoring, and advising, including the monitoring of selected Kosovo cases, such as corruption, organised crime, terrorism, inter-ethnic crimes and war crimes, providing advice on the prosecution and investigation of these crimes. In addition, it provided structured support to develop the capacity and competence of the Kosovo Judicial Council and Kosovo Prosecutorial Council. It also supported the Kosovo Correctional Service with mobile capacity to focus on the handling of high-profile detainees, prisons and detention centres, to improve targeting of serious criminality including terrorism, ${ }^{20}$ corruption, organised crime, and specialised units.

Through its Executive Division (ED), EULEX focused on delivering legal services until the progress of local authorities allowed a complete transition of executive functions to them. This means that EULEX Judges and Prosecutors were embedded in Kosovo institutions and served in accordance with Kosovar law. Joint cases were investigated and prosecuted by mixed teams consisting of Kosovo prosecution authorities and EULEX prosecutors. In these cases, the Executive Division engaged in mentoring a counterpart in the form of peer-to-peer cooperation in their investigation and prosecution. EULEX dealt with highly sensitive cases related to war crimes, terrorism,${ }^{21}$ organised crime, and corruption.

${ }^{19}$ Data on the involvement of EULEX prosecutors in the prosecution of terrorist offences are provided, by Press Office of the European Union Rule of Law Mission in Kosovo (EULEX Kosovo ) on February 11, 2021.

${ }^{20}$ To strengthen the capacity of Kosovo's Special Prosecution Office to effectively deal with emergent challenges in the prosecution of terrorism cases and other serious offences (on 26 September 2019), EULEX, together with the Academy of Justice of Kosovo, organised a two-day intensive workshop on handling terrorism cases for 22 SPRK prosecutors and legal officers. EULEX hosted (on 27 April 2018) a training session on 'Evidential issues surrounding the prosecution of terrorism-related offences: analysis of specific cases and sharing of good practices on digital forensics, the use of internet and turning intelligence into evidence'.

${ }^{21}$ Based on article FDH për EULEX-in: Kontribut $i$ pakontestueshëm, pritshmëritë të papërmbushura dt. 14.06.2018, published in www.htp.FDH për EULEX-in: Kon- 
In addition to the institutions highlighted above, other local and international institutions play an important role in preventing and combating terrorism in Kosovo, whether they are present in Kosovo or located abroad.

\section{Planning the Countering of Terrorism in Kosovo}

It can be argued that the development of countering terrorism without a plan and strategy is like navigating a ship at sea without a compass, meaning that the orientation of navigation is not known; essentially it is not known on which shore of the sea that ship will complete its journey. The Government of the Republic of Kosovo, is aware of the seriousness of the threat of terrorism; it has defined clear policies to prevent and combat this phenomenon in the hope of its successful navigation. Given that terrorism poses a serious threat to both national security and the rule of law in the country as well as the functioning of the state in general, the Government of Kosovo has set as its objective the drafting of national strategies against terrorism, which will plan and enable the most efficient use of material, financial and human resources as well as the systematic and coordinated commitment of all mechanisms against terrorism both at the national and international level. Thusly, the Government of Kosovo has drafted and approved, among other things, the following strategic documents in which the phenomenon of terrorism is addressed:

a. National Strategy of the Republic of Kosovo Against Terrorism 2009-2012; 22

b. National Strategy of the Republic of Kosovo Against Terrorism 2012-2017; $;^{23}$

c. Strategy for the Prevention of Violent Extremism and Radicalism Leading to Terrorism 2015-2020; 24 $^{2}$

d. State Strategy against Terrorism and Action Plan, 2018-2023. ${ }^{25}$

tributi i pakontestueshëm, pritshmëritë të papërmbushura - Telegraf: "According to EULEX data, the judges of this mission from the beginning (January 2008) of the mandate until June 14, 2018 have taken 479 judgements in criminal cases such as corruption, organized crime, terrorism, war crimes and trafficking of human beings.”

${ }_{22}$ National Strategy of the Republic of Kosovo against Terrorism 2009-2012, approved by the Government Of Kosovo, with the Decision No. 08/69, 19.06.2009.

${ }^{23}$ The National Strategy of the Republic of Kosovo against Terrorism 2012-2017, approved by the Government of Kosovo, with the Decision No. 05/92, 19.09.2012.

${ }^{24}$ Strategy for Prevention of Violent Extremism and Radicalism that Leads to Terrorism 2015-2020, approved By the Government of Kosovo on 16.09.2015.

25 State Strategy against Terrorism and Action Plan, 2018-2023, approved by the Government of Kosovo, 09.03.2018. 
In general, these strategic documents contain strategic and specific objectives and define the mechanisms, methods and manners through action plans in order to formulate an effective policy against terrorism, both locally and internationally, which the state of Kosovo will implement in the countering of terrorism.

The implementation of these strategies is also a commitment by the Republic of Kosovo to undertake the maximum so as to counter terrorism in Kosovo and it represents its goal to be an important partner and an integral part of international efforts against terrorism.

Kosovo will cooperate with governments and other international institutions to address common concerns about the threat of terrorism, and is even willing to do so with countries that do not recognise Kosovo. International cooperation is essential for fighting and defeating terrorism.

These strategic documents also determine the will of the institutions of the Republic of Kosovo for good governance, for cooperation and a unified approach of institutions in dealing with security challenges in the Republic of Kosovo.

Finally, for these strategic documents of Kosovo, it can argued that they have helped to increase the institutional capacity needed to prevent and combat terrorism by creating adequate mechanisms, providing the necessary human resources as well as physical, technical, and technological infrastructure. Although these already established mechanisms are functional, it is still necessary to further strengthen them. These strategic documents have been drafted for certain periods of time (three or five years), and are reviewed and re-evaluated by the relevant mechanisms on an annual basis.

\section{Concrete Measures and Activities of the State Institutions of Kosovo in Countering Terrorism}

Despite all the measures taken by Kosovar institutions to prevent terrorism, it is still evident that post-war Kosovo is affected by this phenomenon and it poses not only a challenge but also a concrete threat to the building and functioning of the rule of law.

The emergence of terrorism in Kosovo has been the subject of many projects by a variety of local and international institutions. Based on the results of these studies, it can be said that:

- In the aftermath of 1999's war in Kosovo there has been an increase in violent extremist groups as a result of the global trend of religious radicalism.

- From the total number of 35,000 people recruited from over 100 countries in the world during the 2012-2018 period, around 
400 Kosovars have joined the wars in Syria and Iraq, becoming members of various extremist and terrorist groups such as Islamic State in Iraq, ISIS in Syria and Al Nusra. ${ }^{26}$

- During 2015, the trend of Kosovars going and joining the wars in Iraq and Syria declined, but Kosovo still remains a country in constant danger of the global trend of religious radicalism which is related to the conflicts in Syria and Iraq. ${ }^{27}$

- Kosovo, in these conflicts, has given the largest number of foreign fighters per capita in Europe, two of whom have carried out suicide attacks in Iraq. Some of the others have risen to the top of ISIS' hierarchy. ${ }^{28}$

- Unfortunately, during this 2015 period, some Kosovars carried out terrorist attacks on a number of Western European countries and the USA. ${ }^{29}$

- In spite of the fact that Kosovo is characterised as a country of religious tolerance, the influence of extremist groups in Kosovo has increased over the last two decades. Due to this, the level of perceived religious radicalism in Kosovo has increased. The activities of radical groups and individuals take place both in informal and official religious settings.

- In fact, the signs of radicalisation are constantly present, which means that the risk of terrorist attacks may be higher due to direct calls from ISIS to its supporters to carry out attacks in the homeland after the loss of ground in Syria and Iraq. ${ }^{30}$

Among the main factors pushing Kosovars to carry out terrorist activities are: disappointment with the work of the executive, legislative, and judicial institutions of Kosovo, identity crises and extremist indoctrination, unemployment, poverty and other socio-economic conditions especially the weak education system, institutional corruption, the lack of organised activities for young people, and the social stigmatisation of conservative believers. ${ }^{31}$

As Kosovo faces such a serious situation and threat, the government and the institutions responsible for fighting crime have taken a series of meas-

${ }^{26} \mathrm{UNDP} / \mathrm{Kos}$ ovo, Public pulse analysis on prevention of violent extremism in Kosovo, Prishtina, June 2017, p. 4.

27 G. Kraja, op. cit., p. 6.

28 Ibidem.

29 UNDP/Kosovo, Comprehensive Evaluation of the fighting of violent radicalism in Kosovo, Prishtina 2015, p. 6

$30 \mathrm{UNDP} /$ Kosovo, Public pulse analysis on prevention of violent extremism in Kosovo, Prishtina, June 2017, p. 5.

${ }^{31}$ Ibidem. 
ures and actions countering violent extremism and terrorism which can be ranked according to areas of implementation in two (2) main groups:

a. Measures in the field of criminal prosecution of perpetrators of terrorism, and

b. Measures in the field of international cooperation and institutional capacity building.

\section{Measures in the Field of Criminal Prosecution of Perpetrators of Terrorism}

In the period 2013-2019, Kosovo investigative and justice bodies have carried out a large number of arrests, trials and meetings out of punishment to perpetrators of terrorist acts in Kosovo.

Table 1. Volume, dynamics and structure (transferred, new, in process, adjudicated and unresolved cases) of cases with criminal offences of terrorism in the courts of Kosovo, during the period 2013-2019

\begin{tabular}{|l|c|c|c|c|c|c|c|c|}
\hline $\begin{array}{c}\text { Cases carried over } \\
\text { from previous } \\
\text { years }\end{array}$ & 2013 & 2014 & 2015 & 2016 & 2017 & 2018 & 2019 & Total \\
\hline $\begin{array}{l}\text { New cases with } \\
\text { acts of terrorism }\end{array}$ & 1 & 2 & 5 & 19 & 24 & 19 & 24 & \\
\hline Cases in trial & 1 & 3 & 19 & 22 & 9 & 14 & 3 & $\mathbf{7 1}$ \\
\hline Adjudicated cases & 2 & 5 & 24 & 41 & 33 & 33 & 27 & \\
\hline Unresolved cases & 0 & 0 & 5 & 17 & 14 & 9 & 8 & 53 \\
\hline $\begin{array}{l}\text { Cases carried over } \\
\text { from previous } \\
\text { years }\end{array}$ & 2 & 5 & 19 & 24 & 19 & 24 & 19 & \\
\hline
\end{tabular}

Source: The data presented in the table are provided by the Computer Data System of the Kosovo Judicial Council, in which the data from the monthly reports of all Kosovo courts are recorded.

Table 1 shows that in the courts of Kosovo, during the period 20132019, 71 new criminal cases were filed charged with acts of terrorism, which means an average of 10 such cases per year, while the years with the largest number of new cases are: the year 2016, with 22 subjects or $30.9 \%$ of new cases, then the year 2015, with 19 cases or $26.7 \%$ and finally the year 2018 , with 14 cases or $19.7 \%$ of them. Regarding the trial of criminal cases with acts of terrorism, according to table no. 2 , it is seen that in the period 2013-2019 from 71 cases lodged, for 53 or $74.6 \%$ of those cases, Kosovo courts have ruled upon them. 
Table 2. Volume and dynamics of criminal cases for terrorism offences tried in the courts of the Republic of Kosovo, in the period 2013-2019, as well as the types of sentences imposed for their perpetrators

\begin{tabular}{|l|c|c|c|c|c|c|c|c|}
\hline & 2013 & 2014 & 2015 & 2016 & 2017 & 2018 & 2019 & Total \\
\hline $\begin{array}{l}\text { Criminal cases } \\
\text { prosecuted for } \\
\text { acts of terrorism }\end{array}$ & 0 & 0 & 5 & 17 & 14 & 9 & 8 & 53 \\
\hline Imprisonment & 0 & 0 & 3 & 13 & 11 & 6 & 4 & $\mathbf{3 7}$ \\
\hline Fine penalty & 0 & 0 & 0 & 0 & 1 & 0 & 0 & $\mathbf{1}$ \\
\hline $\begin{array}{l}\text { Conditional } \\
\text { sentence }\end{array}$ & 0 & 0 & 1 & 2 & 2 & 0 & 1 & $\mathbf{6}$ \\
\hline Other penalties & 0 & 0 & 0 & 0 & 0 & 0 & 0 & $\mathbf{0}$ \\
\hline $\begin{array}{l}\text { Solved in any } \\
\text { other manner }\end{array}$ & 0 & 0 & 1 & 1 & 0 & 0 & 1 & $\mathbf{3}$ \\
\hline Acquittal & 0 & 0 & 0 & 1 & 0 & 3 & 2 & $\mathbf{6}$ \\
\hline
\end{tabular}

Source: The data presented in the table are provided by the Computer Data System of the Kosovo Judicial Council, in which the data from the monthly reports of all Kosovo courts are recorded.

From Table 2 it can be seen that starting from 2016 onward, there was an increase in the efficiency of Kosovo courts in relation to cases for criminal offences of terrorism, specifically, from 53 adjudicated cases in 2016, a decision was reached for 17 or $32 \%$ of them, while in 2017 it was set at 14 or $26.4 \%$ of them. Out of 53 cases decided by a verdict, in 47 or $88.6 \%$ of them a trial verdict was obtained, while in 6 cases or $11.3 \%$ of them a verdict of acquittal was imposed. As expected, in the largest number (37 out of 47 cases) or in $78.7 \%$ of them, the convicted persons were sentenced to prison, while in 6 cases or $12.7 \%$, a suspended sentence was handed down, and in one (1) case or $2.1 \%$ of the cases, a fine was imposed.

Some of the cases in which those accused of terrorism offences were found guilty have attracted the attention of the general Kosovar public. Specifically, during 2016, Kosovo courts announced verdicts in several cases with high-profile defendants wherein seven people were sentenced to 42 years in prison (in May), and, respectively, four others were sentenced to 49 years in prison (in June) for their involvement with ISIS. 
Table 3. Volume and dynamics of cases according to the type of criminal offence against the constitutional order and security of the Republic of Kosovo (terrorism, a terrorist act or an act of terrorism), in the courts of Kosovo, during the period 2013-2019

\begin{tabular}{|l|c|c|c|c|c|c|c|c|}
\hline & 2013 & 2014 & 2015 & 2016 & 2017 & 2018 & 2019 & $\begin{array}{c}\text { To- } \\
\text { tal. }\end{array}$ \\
\hline Type of criminal offence & & & & & & & & \\
\hline $\begin{array}{l}\text { Definition of terrorism (Article } \\
\text { 135 CCK) }\end{array}$ & 0 & 0 & 3 & 0 & 0 & 0 & 0 & $\mathbf{3}$ \\
\hline $\begin{array}{l}\text { Commission of the terrorist of- } \\
\text { fence (Article 136 CCK) }\end{array}$ & 1 & 0 & 1 & 4 & 0 & 3 & 0 & 10 \\
\hline $\begin{array}{l}\text { Assistance in the commission of } \\
\text { terrorism (Article 137 KCCP) }\end{array}$ & 0 & 0 & 1 & 1 & 1 & 1 & 0 & 4 \\
\hline $\begin{array}{l}\text { Facilitation of the commission of } \\
\text { terrorism (Article 138 CCK) }\end{array}$ & 0 & 1 & 2 & 1 & 1 & 0 & 0 & 5 \\
\hline $\begin{array}{l}\text { Recruitment for terrorism (Arti- } \\
\text { cle 139 CCK) }\end{array}$ & 0 & 0 & 1 & 3 & 1 & 0 & 0 & 5 \\
\hline $\begin{array}{l}\text { Training for terrorism (Article } \\
\text { 140 CCK) }\end{array}$ & 0 & 0 & 0 & 0 & 0 & 0 & 0 & $\mathbf{0}$ \\
\hline $\begin{array}{l}\text { Incitement to commit a terrorist } \\
\text { offence (Article 141 CCK) }\end{array}$ & 0 & 0 & 0 & 1 & 2 & 1 & 0 & 4 \\
\hline $\begin{array}{l}\text { Concealment or failure to report } \\
\text { terrorists or terrorist groups (Ar- } \\
\text { ticle 142 CCK) }\end{array}$ & 0 & 0 & 0 & 0 & 1 & 0 & 0 & $\mathbf{1}$ \\
\hline $\begin{array}{l}\text { Organisation and participation } \\
\text { in a terrorist group (Article 143 } \\
\text { CCK) }\end{array}$ & 0 & 2 & 9 & 11 & 3 & 7 & 2 & $\mathbf{3 4}$ \\
\hline $\begin{array}{l}\text { Preparation of terrorist offences } \\
\text { or criminal offences against the } \\
\text { constitutional order and security } \\
\text { of the Republic of Kosovo (Arti- } \\
\text { cle 144 CCK) }\end{array}$ & 0 & 0 & 2 & 0 & 0 & 2 & 1 & 5 \\
\hline $\begin{array}{l}\text { Irrelevance of the commission of } \\
\text { a terrorist offence and relation- } \\
\text { ship to terrorist offences (Article } \\
\text { 145 CCK) }\end{array}$ & 0 & 0 & 0 & 1 & 0 & 0 & 0 & $\mathbf{1}$ \\
\hline Total & $\mathbf{1}$ & $\mathbf{3}$ & $\mathbf{1 9}$ & $\mathbf{2 2}$ & $\mathbf{9}$ & $\mathbf{1 4}$ & $\mathbf{3}$ & $\mathbf{7 2}$ \\
\hline
\end{tabular}

32 The data presented in the table are provided by the Computer Data System of the Kosovo Judicial Council, in which the data from the monthly reports of all Kosovo courts are recorded. 
Regarding the concrete criminal offences of this nature perpetrated in Kosov, as can be seen in table 3, one can see that the most frequently committed criminal offence is that of organising and participating in terrorist groups (Article 143 of the CCK), at 34 cases or $47.2 \%$, then the criminal offence of committing terrorist acts (Article 136 of the CCK) at 10 cases or $13.8 \%$ of them, followed then by the criminal offence of facilitating the commission of terrorism (5 cases); recruitment for terrorism (5 cases). Of all the criminal offences of this nature contained in the CCK, only the criminal offence of training for terrorism (Article 140 of the CCK) has not been committed in any of the cases.

During this period, the Kosovo police arrested nearly 200 people suspected of preparing or committing terrorist acts. Among the arrests that have been widely reported in Kosovo are the arrests of seven people in November 2013, followed by arrests in the summer of 2014 when the largest anti-terrorist operation to date took place in Kosovo (during that year, of the 70 individuals arrested on suspicion of terrorism around 40 of them were foreign fighters; returned terrorists) when 59 individuals were arrested on suspicion of terrorist activities, followed by the July 2015 action, when police near Prishtina arrested five suspects for terrorism. November 2016 saw 18 people suspected of terrorism arrested, More arrests which caught the public's eye came in June 2018, when the police arrested five people suspected of planning terrorist attacks in Kosovo and Western European countries; at the same time another individual, originally from Kosovo, was arrested in Germany on an international arrest warrant issued by Kosovo. That person was later extradited to Kosovo.

In order to prove their guilt, criminal proceedings were initiated against individuals arrested for terrorism during this period starting in 2013 when the Directorate against Terrorism initiated 10 such cases. A number of people who have held the position of imam in Kosovo mosques have also been subjected to such criminal investigations.

\section{Measures in the Field of International Cooperation and the Raising of Institutional Capacities}

In Kosovo, during the period 2012-2019, in addition to criminal prosecution and punishment of perpetrators of terrorism, administrative measures were also undertaken against NGOs that in certain ways had helped and supported terrorist activities. Thus, in October 2015, the Minister of Internal Affairs of Kosovo issued an executive order revoking the permits of 16 NGOs suspected of recruiting for ISIS and spreading extremist propaganda. Later, in 2016, Kosovo government authorities suspended 
the activities of 21 NGOs suspected of supporting violent extremism. The Government of Kosovo in its countering of terrorism, and in addition to the field of criminal prosecution, has shown significant success in other areas, such as continuing cooperation with the United States on issues related to the fight against terrorism, making considerable advances in the following areas:

- The State Department's Anti-Terrorism Assistance Program (ATA) has supported Kosovo's participation in a number of border security courses aimed at addressing the travel of foreign terrorist fighters;

- The United States has mentored and assisted law enforcement agencies and judicial institutions in active cases against terrorism, through the:

- Export Control and Related Border Security Program (EXBS): International Criminal Investigative Training Assistance Program (ICITAP);

- Office of Overseas Prosecutorial Development, Assistance and Training (OPDAT) and Office for Defense Cooperation (ODC);

- American provision of training opportunities in various aspects of counter-terrorism;

- The Kosovo Police, the Kosovo Customs Authority and the Kosovo Border Police have been sufficiently trained in counter-terrorism and have been provided with equipment by the United States public bodies and the European Union. Kosovo Border Police regularly updates the list of persons suspected of terrorist and criminal activities and, during 2018, 33 strikes of this list were carried out;

- In the field of preventing and combating terrorist financing, the Kosovo Financial Intelligence Unit (FIU) operates as a member of the Egmont Group;

- Kosovo's Ministry of Justice continues to implement a correctional program, the purpose of which is to strengthen the management of terrorists serving prison sentences, and to create frameworks for the rehabilitation and eventual reintegration of prisoners convicted of terrorism. In May 2018, the Ministry of Internal Affairs announced the establishment of a Division for Prevention and Re-integration, the purpose of which is the reintegration of prisoners who have been imprisoned for terrorist offences after returning from areas of armed conflict (from Syria, Iraq, etc.) including their family members;

- It should also be noted that Kosovo has become a member of the Global Coalition against the Islamic State Group and has taken steps to assist in this effort within its capabilities and capacities. It has focused mainly on curbing the flow of foreign terrorist fighters, in detecting 
and limiting the funding of terrorist groups, and in providing humanitarian assistance to refugees from Syria;

- The Government of Kosovo is part of the network of international and regional cooperation in the field of fighting terrorism. Specifically, it cooperates intensively with officials of Albania and Northern Macedonia to support capacity building against terrorism and regional cooperation in this area;

- Kosovo, as a member of the Global Coalition against the Islamic State Group, has taken measures to assist in this effort within its capabilities and limitations. It focuses mainly on preventing the flow of foreign terrorist fighters, detecting and restricting the financing of terrorist groups, and providing humanitarian assistance to refugees from Syria.

\section{Conclusions}

Terrorism is one of the most serious threats not only to the national security of a given country, but also to international security and the lives of human beings around the globe. During the 14 year study period (2006-2019), and as a result of terrorist acts in the world, 282,431 people lost their lives or, as a per annum average, 20,173 people were killed in terrorist acts.

The threat from terrorism, specifically from Islamic extremism, has increased against Kosovo, supported and partially funded by foreign organisations that propagate extremist ideology and violent extremist groups. More than 400 Kosovar men, women, and children have travelled to areas of armed conflict in Syria and Iraq, to fight either on the side of the Islamic State or on the side of Al Nusra (an Al-Qaeda branch in Syria), around 70 of whom have lost their lives, while 130 have returned to Kosovo and 200 remain in the conflict zones.

The Government of the Republic of Kosovo, aware of the seriousness of the threat from terrorism, has taken concrete measures in certain areas such as legislation; mechanisms for the countering of terrorism; and planning the countering of terrorism and activities in the countering of terrorism. The main mechanisms which play an important role in the countering of terrorism in Kosovo are the Ministry of Internal Affairs; the Kosovo Police; the National Coordinator against Terrorism (KNKT); the State Prosecutor; the Courts; the Kosovo Intelligence Agency; the Ministry of Justice; the Kosovo Security Council; the Financial Intelligence Unit; ICITAP; and EULEX among others.

In the Kosovar courts, during the period 2013-2019, 71 new criminal cases were filed pertaining to acts of terrorism, which represents an aver- 
age of 10 such cases per year, while the years with the largest number of new cases are: the year 2016, with 22 subjects or $30.9 \%$ of new cases, then the year 2015, with 19 cases or $26.7 \%$, and the year 2018 with 14 cases or $19.7 \%$. The most frequently committed criminal offence is the organising of and participating in terrorist groups, as was the case in 34 or $47.2 \%$ of the period's cases. Next, in 10 or $13.8 \%$ of the cases, is the criminal offence of committing terrorist acts, followed by the criminal offence of facilitating the commission of terrorism ( 5 cases); recruitment for terrorism in 5 cases and so on. Between 2013 and 2019, the Kosovo police arrested nearly 200 people suspected of preparing or committing terrorist acts. During the period 2012-2019, in Kosovo, in addition to the criminal prosecution and punishment of the perpetrators of terrorism, administrative measures were also undertaken against NGOs that in certain ways had helped and supported terrorist activities.

The Government of Kosovo, in the countering of terrorism as global threat, and in addition to the field of criminal prosecution, has shown significant success in other areas such as continuing cooperation with the United States on issues related to the fight against terrorism. The Republic of Kosovo, despite its successes in the field of the criminal prosecution of the perpetrators of terrorism and its capacity building and strengthening of cooperation with both the US and other allies in the global fight against terrorism, still continues to face certain challenges which negatively affect the effectiveness of the fight against terrorism that takes place in our country. Those challenges include:

a. Obstructing (blocking) Kosovo's membership in many regional and international organisations. This occurs due to the influence of countries that still do not recognise its independence. This non-membership hinders Kosovo's cooperation with relevant international mechanisms on many issues, including the fight against terrorism. More specifically, due to the objections and non-recognition of Serbia and Bosnia and Herzegovina, Kosovo faces difficulties in participating in regional anti-terrorist initiatives.

b. A 2012 report on terrorism by the State Department states that the situation in northern Kosovo continues to limit the ability of the Government of Kosovo to exercise its authority in that part of the territory of the state, where KFOR and EULEX are responsible for maintaining a peaceful and secure environment as well as strengthening the rule of law, inclusive of the border.

Despite these challenges and difficulties, we consider that the statement encountered in the 2019 Counter-Terrorism Report of the State Department is fair, according to which "Kosovo has shown the political will 
to address the threats related to terrorism and the state possesses the legal framework for doing so. National institutions have also strengthened the capacity of their investigative and prosecutorial bodies, but limited capacity, resources and experience have continued to limit their ability to handle terrorism cases more efficiently".

\section{References}

Demolli H., Terrorizmi, Prishtinë 2002.

Dudley D., The Changing Nature of Terrorism: Fewer Victims but More Countries Affected, https://www.forbes.com/sites/dominicdudley/ (access 20.06.2020).

Dudley D., Terrorist Targets: The Ten Countries Which Suffer Most from Terrorism, https://www.forbes.com/sites/dominicdudley/2019/11/20/tencountriesterrorism/\# (access 20.06.2020).

Global Terrorism Index 2019: Measuring the Impact of Terrorism, Institute for Economics and Peace, Sydney, November 2019.

Goertz S., Islamistischer Terrorismus. Analyse - Definitionen - Taktik, 2. Auflage, C.F. Müller GmbH, Heidelberg 2019.

Howard-Williams R., Terrorism and World Risk Society: Resilience, Resentment, and Spectacle, Printer-friendly version, Series ISIS Media, vol. 10, issue 70, October 2017.

http://data.consilium.europa.eu/doc/document/ST-7906-2004-INIT/en/ pdf, DOI: https://doi.org/10.1055/s-0039-3402906.

https://www.statista.com/statistics/202871/number-of-fatalities-by-terrorist-attacks-worldwide (access 20.05.2020).

https://www.statista.com/statistics/202871/number-of-fatalities-by-terrorist-attacks-worldwide (access 20.05.2020).

Jewish Virtual Library: Statistics on Incidents of terrorism worldwide - 2018, https://www.jewishvirtuallibrary.org/statistics-on-incidents-of-terrorism-worldwide-2018 (access 27.05.2020).

Kraja G., The Islamic State Narrative in Kosovo Deconstructed One Story at a Time, Kosovar Center for Security Studies (KCSS), Prishtina, September, 2017.

Latifi V., Demolli H., Kriminalistika, Prishtinë 2019.

Law no. 05/1-002. On prohibition of joining the armed conflicts outside state territory, approved by the Assembly of Kosovo, March 2015.

Law no. 05/L-096 On the prevention of money laundering and combating terrorist financing, approved by the Assembly of Kosovo, May 2016.

Law no. 06/L-014 On critical infrastructure, approved by the Assembly of Kosovo, March 2018. 
Martins O.B., Ferreira-Pereira C.L., Stepping inside? CSDP missions and $E U$ counterterrorism, "European Security", vol. 21, no. 4, December 2012, DOI: https://doi.org/10.1080/09662839.2012.688814.

No. 06/L-074 The Criminal Code of the Republic of Kosovo, approved by the Assembly of Kosovo, November 2018.

Qerimi I., Einige Fakten und Ansichten des Terrorismus in ex-Fugoslawien. Die Albaner unter der einhundertjährigen jugoslawiscen Herschaft, GRIN Verlg, Munich 2004.

Semini Ll., Bajrami F., 110 Kosovars, mostly children and women, returned from Syria, "The Seattle Times", April 20, 2019, www.seattletimes. $\mathrm{com} /$ nation-world/world/110-kosovars-mostly-children-and-womenreturned-from-syria/ (access 29.01.2021).

The National Strategy of the Republic of Kosovo against Terrorism 20092012, approved by the Government of Kosovo, with the Decision No. $08 / 69,19.06 .2009$.

The National Strategy of the Republic of Kosovo against Terrorism 20122017, approved by the Government of Kosovo, with the Decision No. 05/92, 19.09.2012.

The State Strategy against Terrorism and Action Plan, 2018-2023, approved by the Government of Kosovo, on 09.03.2018.

The Strategy for Prevention of Violent Extremism and Radicalism that Leads to Terrorism, Prishtina, June, 2017.

The Strategy for Prevention of Violent Extremism and Radicalism that Leads to Terrorism 2015-2020, approved by the Government of Kosovo on 16.09.2015.

UNDP/Kosovo, Community Level Recommendations for Preventing Violent Extremism in Kosovo, Prishtina, May 2017.

UNDP/Kosovo, Comprehensive Evaluation of the fighting of violent radicalism in Kosovo, Prishtina, 2015.

UNDP/Kosovo, Public pulse analysis on prevention of violent extremism in Kosovo, Prishtina, June, 2017.

US Department of State (Bureau of Counterterrorism), Country Reports on Terrorism 2012, May 2013.

US Department of State (Bureau of Counterterrorism), Country Reports on Terrorism 2016, July, 2017.

US Department of State (Bureau of Counterterrorism), Country Reports on Terrorism 2018, Realesed, October, 2019.

US Department of State (Bureau of Counterterrorism), Country Reports on Terrorism 2019, June, 2020. 